\title{
Teel sihtkeelepärase keelekasutuse poole: vene- ja soomekeelsete eesti keele õppijate kirjaliku keelekasutuse dünaamika A2- ja B1-tasemel
}

\author{
PILLE ESLON ${ }^{1}$, ANNEKATRIN KAIVAPALU \\ Tallinna Ülikool' ${ }^{1}$ Ida-Soome Ülikool ${ }^{2}$
}

Ülevaade. Artikkel käsitleb vene- ja soomekeelsete õppijate kirjalikku keelekasutust A2- ja B1-tasemel. Kahe õppijarühma eesti keele arengut võrreldakse omavahel emakeelekõnelejate keelekasutuse taustal. Käsitlus põhineb Eesti vahekeele korpuse tekstide sagedasemate ühesuguse morfoloogilise struktuuriga keelekasutusmustrite analüüsil. Uurimistulemustest nähtub, et kahe eri emakeelega õppijate rühma keelekasutus areneb A2-tasemelt B1-tasemele liikudes paljuski sarnaselt, kuid samas on nii mustrite esinemuse kui ka leksikaalgrammatilise varieerumise dünaamikas olulisi kvantitatiivseid ja kvalitatiivseid erinevusi. Venekeelsete õppijate tekstides kasvab B1-tasemel hüppeliselt nii mustrite koguarv kui ka statistiliselt oluliste mustrite arv ja osakaal, kuid sellega ei kaasne mustrite rühmade olulist laienemist ega sõnavara märkimisväärset mitmekesistumist. Soomekeelsete õppijate kirjutistes seevastu kasvab statistiliselt oluliste mustrite osakaal sujuvalt, kuid samas toimub vähemate mustrite alusel õppija sõnavara intensiivne laienemine.

Märksõnad: õppijakeel; kirjalikud tekstid; kontrastiivanalüüs; keelekasutusmustrid; varieerumine; eesti keel; vene keel; soome keel 


\section{Lähtekohti}

Käesolevas artiklis vaadeldakse võrdlevalt kahe eesti keele õppijate rühma, venekeelsete ja soomekeelsete õppijate kirjalikku keelekasutust. Keele omandamise uurimises on võrdleval lähenemisel pikad traditsioonid, alustades strukturalistlik-kontrastiivsest analüüsist ja kontrastiivse keeleuurimise tugevast ja nõrgast hüpoteesist ning lõpetades vahekeele (õppijakeele) võrdleva analüüsiga (ingl contrastive interlanguage analysis, Granger 1996). Eri lähtekeeli kõnelevate õppijate keeleloome võrdlus on keskne ka keeltevahelise mõju (ingl cross-linguistic influence) uurimisel nii võrdlus- (ingl comparison-based approach) kui ka avastuspõhise (ingl detection-based approach) lähenemise korral (Jarvis 2010: 169192). Emakeelekõnelejate (K1) ja õppijakeele (K2) kasutuse võrdlemisel on levinud võtmesõna n-grammide (ingl key $n$-grams) ja võtmestruktuuride (ingl key structures) analüüs (vt ülevaadet Kyle jt 2013: 242-250; Ivaska 2015: 23-44).

Artiklis keskendutakse kahe eri emakeelega óppijate rühma sihtkeele kasutusele. Vene- ja soomekeelsete õppijate keelekasutus on valitud uurimisobjektiks kahel põhjusel: esiteks on tegemist kahe suurima eesti keele õppijate rühmaga ja teiseks on esimesel juhul õppijate emakeel sihtkeelest erinev (indoeuroopa keel), teisel juhul aga sihtkeelele lähedane sugulaskeel (läänemeresoome keel). Õppijate emakeele mõju artiklis siiski süstemaatiliselt ei käsitleta, kuid analüüsi käigus esitatakse tähelepanekuid nende rühmade keelekasutuse sarnasuste ja erinevuste kohta, millest osa võib olla tingitud õppijate emakeeltest. Venekeelsed õppijad on omandanud eesti keelt keelekeskkonnas teise keelena, soomekeelsed õppijad formaalse keeleõpetuse kaudu väljaspool keelekeskkonda. Artiklis käsitatakse mõlemat rühma sihtkeele õppijatena, kuid samas võimaldab rühmade erinev taust selgitada keelekeskkonna rolli sihtkeele omandamisel.

Siinne kahe õppijate rühma omavaheline võrdlus ja nende keelekasutuse võrdlus emakeelekõnelejatega põhineb sagedasemate keelekasutusmustrite analüüsil. Keelekasutusmuster on statistiliselt eristuv 
TEEL SIHTKEELEPÄRASE KEELEKASUtUSE POOLE

tekstitasandi element, milles erinevaid sõnavorme tüüpiliselt koos kasutatakse. Mustrid leitakse mahukast tekstikorpusest formaalsete tunnuste põhjal automaatselt programmiga Klastrileidja (Ots 2012), mis töötab andmekaeve põhimõttel. Mustrite pikkus on paindlik (tavaliselt kuni neli järjestikust komponenti), mustrite vormiline külg oleneb objektist ja uurimuse eesmärkidest. Nii nagu lausetasandi elemente, konstruktsioone, analüüsitakse ka mustreid sageli just kahest-kolmest komponendist koosnevate üksustena, kuid sõnavormide kombineerumine toimib neis tekstiliste, mitte kategoriaalsete seoste alusel. Seetõttu on sõnavara ja vormistik mustri piires kas stereotüüpne, leksikaalselt, grammatiliselt ja funktsionaalselt kinnistunud või teatud piirides varieeruv. Mustrid toovad esile keele elementide kommunikatiivse ning funktsionaalse võimekuse, mis konkretiseerub vaid tekstikasutuses. Suure esinemusega mustrid sisaldavad keele aktiivset sõnavara ja grammatikat. Mustrite klassifikatsioon põhineb mustri sõnaliigijärjendil ehk morfoloogilisel struktuuril, mustrite leksikaalsetel, morfosüntaktilistel ja funktsionaalsetel erinevustel ning mustri kasutamise sagedusel tekstis (Eslon \& Allkivi-Metsoja 2018). Siinse K1 ja K2 keelekasutusmustrite võrdleva analüüsi aluseks on ühesuguse morfoloogilise struktuuriga mustrid, mille esinemust ja keelelist varieerumist võrreldakse kolme eesti keele kasutajate rühma vahel. K2 mustrite võrdlemisel K1 mustritega toetutakse varasematele eesti keelekasutuse uurimustele (nt Trainis \& Allkivi 2014: 283-306).

Analüüsitavad A2- ja B1-taseme morfosüntaktiliselt märgendatud tekstid on pärit Eesti vahekeele korpusest. A2-taseme valimis on 32 venekeelsete õppijate teksti (4915 sõnet) ja 51 soomekeelsete õppijate teksti (6601 sõnet). B1-tasemel on venekeelsete õppijate tekste 182 (38 685 sõnet), soomekeelsete õppijate tekste 114 (23 024 sõnet). Nimetatud kaht alamvalimit töödeldi programmiga Klastrileidja, et leida morfosüntaktiliselt märgendatud korpusainestikust süntaksianalüsaatori formaalkeele märgendite regulaarse koosesinemise põhjal kolmest komponendist koosnevad morfosüntaktilised mustrid. Venekeelsete õppijate A2-taseme tekstides leidus niisuguseid mustreid kokku 
2865, soomekeelsetel õppijatel 3096. B1-tasemel oli venekeelsete õppijate tekstides kokku 22201 mustrit, soomekeelsetel 12035 mustrit. Keelekasutuse analüüsist jäeti välja kõik ainukordsed juhtumid ning need, mis kordusid kaks, kolm ja neli korda, kuna arvutuste kohaselt ei mõjuta nende esinemus analüüsi tulemusi (vt Eslon \& Matsak 2009). See tähendab, et reaalselt analüüsiti venekeelsete õppijate A2-taseme tekstide keelekasutust 203 (7,1\% kõikidest mustritest) ja soomekeelsete õppijate puhul 227 (7,3\% kõikidest mustritest) kolmest komponendist koosneva mustri põhjal. Vastavad arvud B1-tasemel on 4363 $(19,7 \%)$ ja $1132(9,4 \%)$ mustrit. Nimetame neid aktiivselt kasutatud mustriteks.

Viis ja rohkem korda esinenud mustrite seast on valitud need, mida kasutavad mõlema rühma õppijad. Analüüsi keskmes on ühelt poolt samasuguse esinemusega mustrid ja teisalt mustrid, mille kasutamine erineb. Eesmärk on selgitada, kuidas muutub eesti keele õppija kirjalik keelekasutus algaja keelekasutaja (A2) tasemelt iseseisva keelekasutaja (B1) tasemele liikudes. Võrdlus algab keelekasutusmustrite esinemissageduse analüüsiga, järgneb kahe rühma õppijate keelekasutuse sarnaste joonte ja erinevuste esiletoomine ning võrdlus samade mustrite kasutamisega K1-s.

\section{Soome- ja venekeelsete õppijate A2- ja B1-taseme tekstide keelekasutusmustrite võrdlev analüüs}

\subsection{Mustrite esinemissagedus}

Vene- ja soomekeelsete eesti keele õppijate keelekasutusmustrite esinemissagedus ja osakaal on esitatud tabelis 1 . 
TEEL SIHTKEELEPÄRASE KEELEKASUtuse POOLE

TABEL 1. Vene- ja soomekeelsete óppijate A2- ja B1-taseme

keelekasutusmustrite esinemissagedus ja osakaal

\begin{tabular}{|l|c|c|c|c|}
\hline \multirow{2}{*}{\multicolumn{1}{|c|}{ Arvandmed }} & \multicolumn{2}{|c|}{ A2-keeleoskustase } & \multicolumn{2}{c|}{ B1-keeleoskustase } \\
\cline { 2 - 5 } & $\begin{array}{c}\text { vene- } \\
\text { keelsed } \\
\text { óppijad }\end{array}$ & $\begin{array}{c}\text { soome- } \\
\text { keelsed } \\
\text { óppijad }\end{array}$ & $\begin{array}{c}\text { vene- } \\
\text { keelsed } \\
\text { opppijad }\end{array}$ & $\begin{array}{c}\text { soome- } \\
\text { keelsed } \\
\text { oppijad }\end{array}$ \\
\hline Mustrite arv kokku & 2865 & 3096 & 22201 & 12035 \\
\hline $\begin{array}{l}\text { Statistiliselt oluliste } \\
\text { mustrite arv }\end{array}$ & 203 & 227 & 4363 & 1132 \\
\hline $\begin{array}{l}\text { Statistiliselt oluliste } \\
\text { mustrite osakaal }\end{array}$ & $7,1 \%$ & $7,3 \%$ & $19,7 \%$ & $9,4 \%$ \\
\hline $\begin{array}{l}\text { Statistiliselt oluliste } \\
\text { mustrite rühmade arv }\end{array}$ & 18 & 19 & 20 & 18 \\
\hline
\end{tabular}

Toodud andmete põhjal on vene- ja soomekeelsete õppijate A2-taseme tekstides aktiivselt kasutatud mustrite esinemus nii mustrite arvu (venekeelsetel 203, soomekeelsetel 227) kui ka statistiliselt oluliste mustrite osakaalu (vastavalt 7,1\% ja 7,3\%) poolest sisuliselt samas suurusjärgus. Mustri kolme komponendi sõnaliigiline järgnevus võimaldab jagada need venekeelsetel 18 ja soomekeelsetel 19 rühma vahel.

B1-tasemel on olukord muutunud: venekeelsete õppijate tekstides on kasvanud hüppeliselt nii mustrite koguarv kui ka statistiliselt oluliste mustrite arv ja osakaal (19,7\%). Samas ei kaasne sellega mustrite rühmade erilist laienemist, sest võrreldes A2-tasemega on lisandunud vaid kaks rühma (4363 mustrit ja 20 morfoloogilist struktuuri). Soomekeelsete õppijate kirjutistes kasvab statistiliselt oluliste mustrite osakaal sujuvalt $(9,4 \%)$, võrreldes A2-tasemega on üks mustrite rühm vähem (1132 mustrit ja 18 morfoloogilist struktuuri).

B1-taseme mustrite kasutust on eelnevalt võrreldud Katrin Voolaiu (2018) magistritöös Ta on selgitanud, et venekeelsete õppijate tekstides leidub tunduvalt suurem hulk leksikaalgrammatiliselt varieeruvaid mustreid kui soomekeelsetel (vt Voolaid 2018: 29 jj). Siinse analüüsi üldstatistilised andmed kinnitavad seda seisukohta. Täpsemalt: kõrvuti 
sageli esinevate mustritega kasutavad venekeelsed õppijad B1-tasemel palju niisuguseid, mille esinemus kõigub $2 \%$ ja $0,50 \%$ vahel, nt määrsõna-omadussõna-märssõna (väga oluline $k a$, väga raske materiaalselt), sidesõna-sidesõna-asesõna (Aga kui ma, Sest et ma, Ja kui ma). Seevastu soomekeelsetel õppijatel on B1-tasemel mustreid üldse poole vähem ja ühegi statistiliselt olulise mustri esinemus ei jää alla $2 \%$. Igas mustrite rühmas eristub kaks-kolm levinud leksikaalgrammatilist varianti, ülejäänud mustreid on kasutatud tunduvalt harvem või pole neid üldse esile tulnud. Näiteks asesõnaga algavaid mustreid on kokku seitse, suurim osakaal on järjenditel asesõna-tegusõna-määrsõna (Ma olen siiski, ma ujun palju) ja asesõna-tegusõna-tegusõna ( $M a$ ei mäleta, Ma ei taha), vastavalt $43 \%$ ja $24 \%$. Ülejäänud asesõnaga algavate mustrite esinemus kõigub $12 \%$ ja $4 \%$ vahel. Venekeelsetel õppijatel leidub asesõnaga algavaid mustreid rohkem ja seetõttu on ka nende esinemus ühtlasem: viie sagedama mustri osakaal kõigub $28 \%$ ja $11 \%$ vahel, ülejäänud kaheksa mustri osakaal jääb $4 \%$ ja $1 \%$ vahele. Niisiis on venekeelsete õppijate tekstides asesõnaga algavate struktuuride varieeruvus suur, soomekeelsetel aga poole väiksem. Analoogne seis tuleb esile kõikide mustrite rühmadega.

Eespool toodud andmed näitavad, et venekeelsete õppijate sihtkeele oskus areneb B1-tasemel soomekeelsetest õppijatest erinevalt mustrite kasutussageduse suurenemise ja keelekasutuse keerukust väljendava laiema varieeruvuse suunas. Võib arvata, et keelekeskkond toetab venekeelseid õppijaid A2-taseme algajast keelekasutajast B1-taseme iseseisvaks keelekasutajaks kujunemisel: neil on keelekeskkonna toel tekkinud teatud kindlustunne ja julgus katsetamaks erinevaid sõnastamisviise.

\section{2. Ühesuguse ja lähedase esinemusega mustrid}

\subsubsection{A2-tase}

A2-tasemel on vene- ja soomekeelsete õppijate tekstides kokku 12 sama struktuuriga mustrit (joonis 1). 


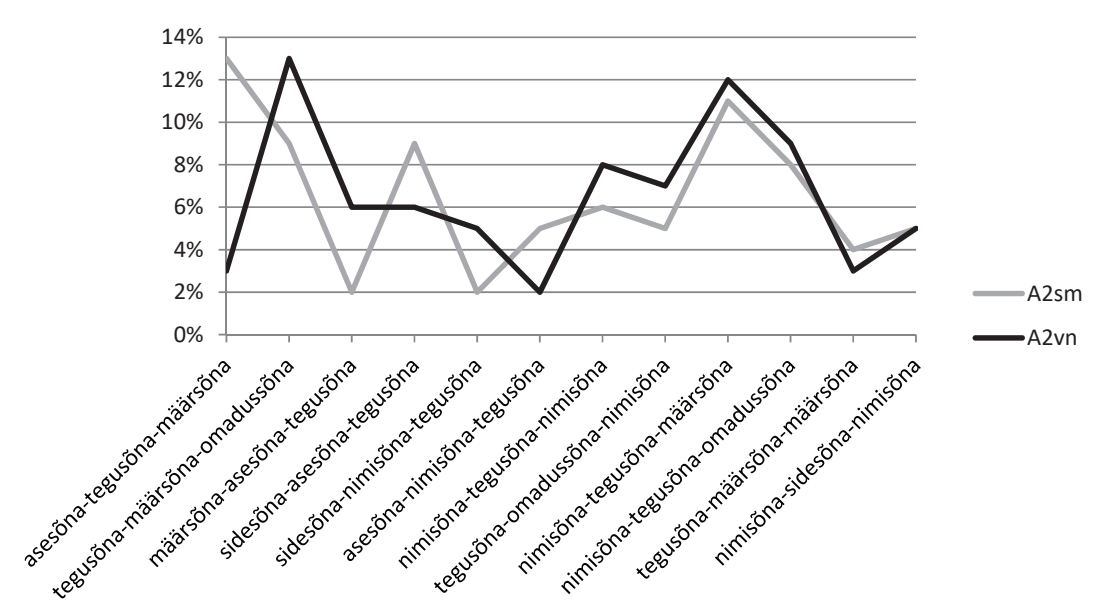

Joonis 1. Sama struktuuriga mustrite esinemus soome- ja venekeelsete óppijate A2-taseme tekstides

Võrdne esinemus on vene- ja soomekeelsete õppijate tekstides vaid mustril nimisõna-sidesõna-nimisõna. Tegemist on lihtsa mustriga, kus rinnastav sidesõna ja seob erinevaid teemasõnu, mida õppijad omandavad kodu ja peret kirjeldades: sm - isaisa ja isaema, ${ }^{\star}$ elekterpliit <elektripliit> ja ${ }^{\star}$ lettlaud?, kirjutuslaud ja riiul, ${ }^{\star}$ düss <dušš > ja koduapteek, söögilaud ja kirjutuslaud, jäähoki ja jääpall, óde ja vend, vannituba ja köök, kapp ja külmkapp, Reede ja laupäev, pidu ja ^óbutsedame <lõbu(tsemine)>; vn - Tualett ja vannituba, Magamistuba ja köök, magamistuba ja elutuba, tualett ja ${ }^{*}$ vanituba <vannituba>, ${ }^{*}$ tull ja kardin $<$ tüllkardin ja külgkardin?>, mahlapress ja hakklihamasin, pann ja kann, sibul ja porgand, tee ja ${ }^{*} k o f f e e<\mathrm{kohv}>$, silmaring ja huviring.

Väga lähedane on vene- ja soomekeelsete õppijate A2-taseme tekstides kolme mustri esinemus (vahe osakaalus vaid 1\%): nimisõnategusõna-määrsõna, nimisõna-tegusõna-omadussõna ja tegusõnamäärsõna-määrsõna.

Mustri nimisõna-tegusõna-määrsõna esinemus on venekeelsetel õppijatel suurem kui soomekeelsetel: vn - raha on väga, raha on palju, 
linn on väga, karjäär on väga, elu on väga, Haridus on väga, Vanemad on väga, ${ }^{*}$ rahvalaulad <rahvalaulud $>$ on väga, Sõbrad on väga, ${ }^{*}$ Venetsias $<$ Veneetsias> on väga, ${ }^{*}$ Sektsioonkappis <-kapis> on palju; sm - töökoht on väga, õeke on niivõrd; saba jääb kinni, nokk jääb kinni; suvi tuleb ruttu, päike tõuseb vara; Suvel on palju, Laual on ka, Suvel on samuti; majas on ka, Magamistoas on ka. Sihtkeeles kasutatakse mustrit väga sageli, nt helk kumas otsekui, töö edenes vaevaliselt; isa oli seal, kool oli tookord, meel oli väga.

A2-tasemel on soome- ja venekeelsed õppijad sarnaselt emakeelekõnelejaga eelistanud nimisõna aluse (elu on väga) ja käändelise määrusena $\left({ }^{*}\right.$ Venetsias $<$ Veneetsias $>$ on väga, Laual on $\left.\mathrm{ka}\right)$. Kuigi nimisõnade valik piirdub konkreetsete nimisõnade, harvem koha- ja isikunimedega, on õppijate nimisõnade pagas siiski üsna mitmekesine. Sama ei saa öelda tegusõnade ja määrsõnade kohta. Öeldise vormistamisel kasutavad mõlema rühma õppijad abitegusõna olema kindla kõneviisi oleviku ainsuse 3. pöördes, soomekeelsed lisaks ka täistähenduslikke tegusõnu (nt suvi tuleb ruttu, päike tõused vara).

Määruse puhul esineb soomekeelsetel õppijatel erinevat liiki määrsõnu, millel on erinevaid funktsioone, samas kui venekeelsete õppijate tekstides eelistatakse rõhusõna väga (harva palju). Abitegusõna olema ainukasutus ja rõhusõna väga valdav kasutamine loob venekeelsetel õppijatel aluse mustri stereotüüpsuse arenemiseks. Seevastu soomekeelsete õppijate tekstides esineb erinevaid täistähenduslikke tegusõnu ja määrsõnu, mis viitab sihtkeelepärasele keelekasutusele - emakeelekõnelejatel on mustris nimisõna-tegusõna-määrsõna tegusõnade ja määrsõnade leksikaalne ning määrsõnade funktsionaalne mitmekesisus suur.

Ka muster nimisõna-tegusõna-omadussõna on A2-tasemel venekeelsetel õppijatel veidi rohkem levinud kui soomekeelsetel: vn - korter on suur, pere on väike, haridus on tähtis, köök on *póhjapolne <põhjapoolne >, elutuba on päikesepoolne, palk on madal; Pórandal on ilus, ${ }^{{ }^{*} L a e l}$ $<$ laes $>$ on suur; sm - isa on *kuuskümne <kuuekümne>, Magamistuba on väike, riidekapp on täis, pere on väike, Söögilaud on punane, ${ }^{\star}$ sõberTommi 
<sõber Tommi> on kallis, suvi on soe, ilm on hea, õde on tüse; Seinal on ilus, Põrandal on väike, Tüdrukul on tore. Sihtkeeles ei mahu muster nimisõnaga algavate mustrite seas statistiliselt oluliste hulka.

Õppijatel langeb mustri morfosüntaktiline varieerumine ühte: nimisõnade valik on piiratud kodu, pereliikmete, sõprade nimetamise ja esemete paigutusega ruumis, abitegusõna olema kasutatakse tüüpiliselt kindla kõneviisi oleviku ainsuse 3. pöördes, omadussõna ainsuse nimetavas käändes iseloomustab nimisõnaga tähistatud esemeid või nähtusi. Venekeelse õppija emakeele mõju avaldub üksiknäidetes, nt ${ }^{\star}$ Lael $<$ laes $>$ on suи (ilus), vn на потолке 'lae peal, lael' висит красивая люстра laes ripub ilus lühter (laelamp).

Mustrit tegusõna-määrsõna-määrsõna kasutatakse üldiselt harva, ent soomekeelsetel õppijatel esineb see veidi sagedamini: sm - on ikka $k a$, on sageli üleliia, on tavaliselt sportlikult, on liiga palju, on ometi väga, on ${ }^{*}$ tavalliselt <tavaliselt> isegi; vn - on väga tihti, on ka väga, on väga palju, on vaja palju. Sihtkeeles on muster nii leksikaalselt kui ka grammatiliselt rikkalik, avades määrsõnade funktsionaalse võimekuse tekstis, sh kahest erinevast määrsõnast koosneva tähendusterviku moodustumine. See näitab kätte suuna, milles õppija keeleoskust arendada.

Venekeelsed õppijad kasutavad mustrit kui leksikaalset ja grammatilist stereotüüpi (abitegusõna olema kindla kõneviisi oleviku 3. pöördes + kaks omavahel ning teiste määrsõnadega kombineeruvat määrsõna väga ja palju). Soomekeelsetel õppijatel on määrsõnade liigid ja funktsioonid üsna mitmekesised, määrsõnade kombineerimisel ei esine stereotüüpe, nt rõhusõnu $k a$ ja nii, määrasõnu ometi, isegi, väga jt kasutatakse millegi esiletõstmiseks, $l t$-lópulisi viisimäärusena (sportlikult), hulgamäärusena (palju), ajamäärusena (tihti) jm.

Liikumaks sihtkeelepärasema keelekasutuse suunas tuleb mustri tegusõna-määrsõna-määrsõna puhul silmas pidada kahte asja: a) öeldise funktsioonis ei saa eelistada vaid abitegusõna olema, tegusõnade pagasit on vaja oluliselt laiendada erinevate täistähenduslike tegusõnadega; b) kaks järjestikust määrsõna võivad moodustada tähendusterviku, neid hääldatakse sõnana - alus liitmäärsõnade tekkeks (vt Eslon 2014). 


\subsubsection{B1-tase}

B1-tasemel (joonis 2) on 35 mustri hulgas kolm niisugust mustrit, mille esinemus langeb soome- ja venekeelsetel õppijatel kokku (määrsõnategusõna-määrsõna; tegusõna-määrsõna-nimisõna ja tegusõna-tegusõna-omadussõna), ning kaks niisugust, mille esinemus on lähedane (asesõna-tegusõna-omadussõna ja nimisõna-tegusõna-tegusõna). Ka nende mustrite leksikaalgrammatiline vormistus võib erineda.

Mustris määrsõna-tegusõna-määrsõna erineb õppijatel ajavormi valik: venekeelsed kasutavad läbivalt abitegusõna olema kindla kõneviisi olevikus (Siin on väga, praegu on palju) ja soomekeelsed lihtminevikus (sees oli väga, Seal oli palju). Esimene määrsõna on tavaliselt kohamäärus (vn - seal, lähedal, siin; sm - seal, sees), teise määrsõnana kordavad venekeelsed õppijad väga, palju ja ka ning soomekeelsed väga, palju ja nii. Sihtkeeles eelistatakse mustrit lause alguses: kohatähenduslikule määrsõnale Siin või rõhusõnale Nii järgneb tegusõna olema oleviku ainsuse 3. pöördes (Trainis \& Allkivi 2014: 288).

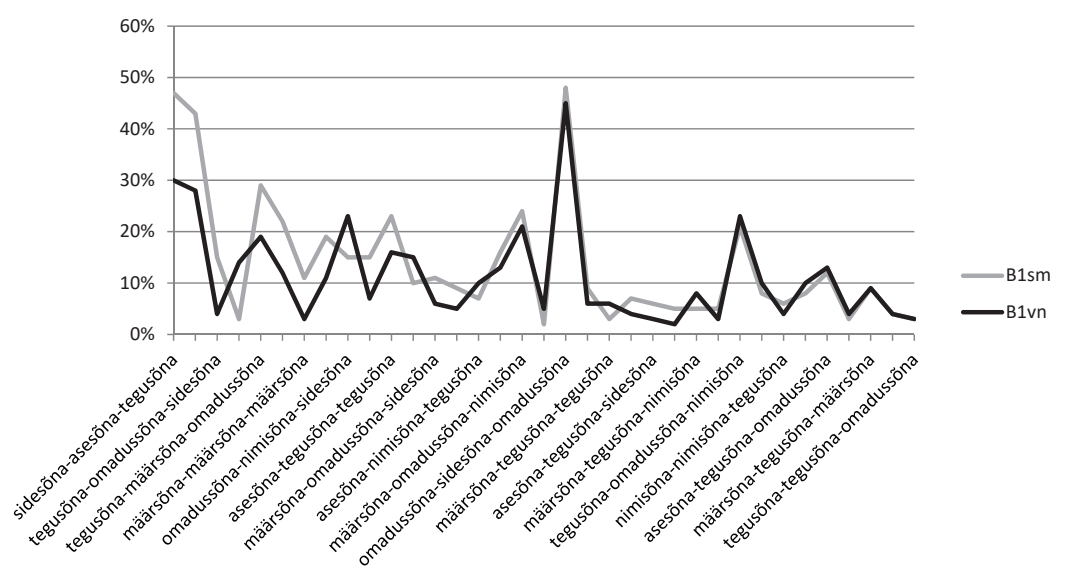

Joonis 2. Sama struktuuriga mustrite esinemus soome- ja venekeelsete oppijate B1-taseme tekstides 
Mustris tegusõna-määrsõna-nimisõna kasutavad venekeelsed õppijad abitegusõna olema kindla kõneviisi olevikus põhiliselt kolme liiki kontekstis: a) hulgasõnafraasiga, kus nimisõna on mitmuse osastavas käändes, nt on palju ${ }^{\star}$ taime, ${ }^{*}$ lille <taimi, lilli>, ${ }^{*}$ sõjaid <sõdu>, *toitusi <toite>, kauplusi, inimesi, ühikaid, harvem ainsuse osastavas käändes, nt on vähe ruumi; b) modaalsõnaga vaja, kus nimisõna on ainsuse osastavas käändes, nt on vaja ${ }^{*}$ keeleoskus <keeleoskust>, ${ }^{*}$ külmkapp $<$ külmkappi külmikut>; c) nimisõnaga ainsuse nimetavas käändes, nt on ka köögikapp, saun, ${ }^{*}$ Poliklinik < polikliinik>. Kasutatakse erinevaid nimisõnu, raskusi tekitab osastava käände vormi moodustamine.

Soomekeelsete õppijate kirjutistes esineb tegusõna nii olevikus kui ka lihtminevikus: a) olevik - on nü̈̈d märts, on veel ${ }^{\star}$ raskuset $<$ raskused> (soome emakeele mõju õigekirjale), on ka ehitus; b) lihtminevik oli juba öö, oli ka hotell, oli peaaegu taevas. Vahelduvad nimisõna kääne ja arv, määrsõnakordusi ei esine.

Niisiis ei kasuta soomekeelsed õppijad mustris tegusõna-määrsõnanimisõna ei hulgasõnafraasi ega modaalpredikaati, samas on venekeelsetel õppijatel need fraasitüübid kasutuses isegi siis, kui selleks pole vajadust.

Sihtkeeles kuulub muster tegusõna-määrsõna-nimisõna statistiliselt oluliste hulka. Üle poole analüüsitud näidetest sisaldab abitegusõna olema kindla kõneviisi lihtmineviku ainsuse 3. pöördes, nimisõna ainsuse nimetavas käändes on öeldistäite funktsioonis, nt oli rohkem hingearst, oli teadagi kaunitar. Ülejäänud pooltel juhtudest kasutatakse öeldisena erinevaid täistähenduslikke tegusõnu. Määrsõnal on mustris väga erinevaid funktsioone, k.a subjektiivse hinnangu väljendamine. (Trainis \& Allkivi 2014: 291) Järelikult oleks selle mustri alusel mõttekas laiendada õppijate sõnavara, omandada uusi tegusõnu, määrsõnu ja nimisõnu, et millestki jutustades või isikuid ja nähtusi kirjeldades saaks edastada erinevat infot ning avaldada oma arvamust.

Mustri tegusõna-tegusõna-omadussõna esinemus on õppijatel väike, sama kehtib sihtkeele osas (vt Trainis \& Allkivi 2014: 292). Tegemist on üldeitusega Ei (ei) ole + missugune (milline). Leksikaalselt 
varieeruvad ainult omadussõnad, ühtki neist pole korduvalt kasutatud, v.a venekeelsetel õppijatel sõna suur: vn - Ei ole suur, ei ole sarnane, ei ole hea jne; sm - ei ole kiire, ei ole kindel, ei ole väärtuslik jne.

Lähedase esinemusega on mustrid nimisõna-tegusõna-tegusõna ja asesõna-tegusõna-omadussõna. Mustri nimisõna-tegusõna-tegusõna esinemus on väike, muster on rohkem levinud venekeelsetel õppijatel. Suurim erinevus õppijate vahel seisneb kõneliigi ja ajavormi eelistustes: vn - eitava kõne olevik, nt elu ei ole, inimene ei saa (ei tee, ei otsi), korteris ei ole, Majas ei ole; sm - jaatava kõne täisminevik, nt Köögipõrand on kaetud, korter on erastatud. Venekeelsete õppijate B1-taseme tekstides oli vaid kaks jaatava kõne näidet (Inimene peab olema ja Haridus peab olema) ning soomekeelsetel esines eitav kõne harva (Eestis ei ole, Soomes ei ole, Eestis ei kasva). Ka tegusõnade valik erineb: venekeelsed õppijad eelistavad abitegusõna olema, soomekeelsed aga täistähenduslikke tegusõnu.

Sihtkeeles on mustril nimisõna-tegusõna-tegusõna kolm levinud varianti, kus nimisõnale nimetavas käändes järgneb a) tegusõna eitava kõne olevikus või lihtminevikus, nt isa ei lähe, uhkus ei lubanud; b) tegusõna mineviku liitaja vorm - enneminevik või täisminevik, nt pilk oli otsinud, tähtedega oli kirjutatud, Tehvan on näinud; c) tegusõna pöördeline vorm koos ma- või da-tegevusnimega, nt naine võib sattuda, juuksed läikima pani. Loetletud süntaktilistes struktuurides on nimisõna enamasti aluse funktsioonis, öeldisena kasutatud tegusõnade valik on rikkalik nagu ka nende grammatiline varieerumine. Ühelt poolt teeb see mustri omandamise õppija jaoks üsna keeruliseks - eriti, kui me pole teadlikud loetletud kasutusreeglitest. Teisalt aga näitavad mustri nimisõna-tegusõna-tegusõna kolm levinud varianti, et mustri morfosüntaktilises varieerumises valitseb süsteem, mida teades saab mustrit kergesti omandada ja aktiivselt kasutama hakata.

Mustri asesõna-tegusõna-omadussõna esinemus on õppijatel keskmine, venekeelsetel on see grammatiliselt varieeruvam kui soomekeelsetel. Sihtkeeles pole muster oluliste hulgas.

Traditsiooniliselt eelistavad venekeelsed õppijad mustri alguses näitavat asesõna see (See), harvem isikulist asesõna ma $(M a)$. Harjumus- 
TEEL SIHTKEELEPÄRASE KEELEKASUTUSE POOLE

päraselt kasutatakse ka abitegusõna olema kindla kõneviisi oleviku ainsuse 1. ja 3. pöördes, harva lihtmineviku 1. pöördes. Muster lõpeb omadussõnaga ainsuse nimetavas käändes. Näiteks: See on suur, see on hea, see on suurepärane, see on tore, ma olen kindel, ma olen õnnelik, Ma olin rõõmus, ma olin seitsmeaastane jne. Oma kodu ja elamist kirjeldades on korduvalt kasutatud täistähenduslikku tegusõna elama: Ma elan viiekorruselises (neljakorruselises, üheksakorruselises, kolmetoalises, väikeses) majas, korteris.

Soomekeelsetel õppijatel algab muster samuti näitava asesõnaga See (see), järgnevad abitegusõna olema kindla kõneviisi oleviku ainsuse 3. pöördes ja omadussõna ainsuse nimetavas käändes: See on võimalik, see on väike, see on ilus, see on vana, see on kallis, see on hea, see on magus, see on suur, see on erinev. Ainsuse 1. isik on tavaliselt omaja funktsioonis: Mul on väike, mul on tore, mul on hea, minul on vaba.

\subsection{Vene- ja soomekeelsete õppijate erinev mustrikasutus: kaassõna ja määrsõna}

Mustrite võrdlev keeleanalüüs toob kõrvuti ühtelangeva ja lähedase esinemusega mustrite ühis- ja erijoontega välja ka ühe olulise erinevuse vene- ja soomekeelsete õppijate vahel, mis on suuresti seotud kaassõna ja määrsõnaga.

\subsubsection{A2-tase}

A2-tasemel esineb vaid venekeelsetel õppijatel tagasõna sisaldavaid mustreid ( ${ }^{\star}$ Lae peale <lakke> on; Paremal seina juures; mille juures on külmik jt), neist sagedam sõnaliigi järgnevus on nimisõna-kaassõnategusõna, nt Akna ees on, seina juures on, Inimese ümber on. Soomekeelsetel õppijatel taolised mustrid puuduvad, sihtkeeles eelistatakse aga hoopis mustrit tegusõna-nimisõna-kaassõna, milles on tüüpiliselt kohta väljendavad tagasõnad poole (liikus ukse poole, läks kodu poole, astub kunstihoone poole, tuleb kaitsetu poole); juures - juurde (istus karja 
juures, käis poe juures; astus tüdruku juurde, läks kapi juurde); alt - all (tuli okastraadi alt, kobas riiuli alt; on kardinamustri all); kõrval - kõrvale (seisis puuvirna kõrval; jäi restorani kõrvale) ning peal - peale (oli pooli peal; mustas raua peale). Tegusõna on tavaliselt kindla kõneviisi lihtmineviku (harva oleviku) ainsuse 3. pöördes, märkides kellegi liikumissuunda, kellegi-millegi paigal olekut, asetsemist või asumist, nt kummardus töö (sahtli) kohale, liikus ukse poole, läks kapi juurde, astus tüdruku juurde, seisis puuvirna kõrval, tuli okastraadi alt, oli pooli peal (vt Eslon 2017: 42-43).

Soomekeelsete õppijate A2-taseme tekstides seevastu tulevad esile määrsõnaga algav (nt üsna väike linn, nii meeldiv inimene, liiga kuum ilm, väga tore suvila) ja määrsõnaga lóppev muster (nt ei ole piisavalt, ei ole veel), mida omakorda ei kasuta venekeelsed õppijad. Sihtkeeles on erinevaid määrsõna sisaldavaid mustreid, milles määrsõnal on hulgaliselt semantilisi, pragmaatilisi ja ekspressiivseid funktsioone. Nende alusel moodustub uusi liitseid üksusi, ühend- ning väljendtegusõnu jmt (vt ka Jürine \& Habicht 2017). Just määrsõna sisaldavate mustrite osas on soomekeelsed õppijad (erinevalt venekeelsetest) sihtkeelele lähemal, sest nad eelistavad A2-tasemest alates eesti keeles levinud mustreid, kus nt tegusõna ja määrsõna ees seisab kas isikuline asesõna ( $m a$ saan $k a$, ma võin siis) või nimisõna (Suvi tuleb ruttu, Elutoas on ka, saba jääb kinni). Ning ehkki mustri tegusõna-määrsõna-nimisõna esinemus on soomeja venekeelsete õppijate A2-taseme tekstides lähedane, kasutavad venekeelsed õppijad selles stereotüüpselt vaid rõhusõna väga (raha on väga, Iseloom on väga, sõbrad on väga), samas kui soomekeelsetel õppijatel esineb hulk määrsõnu erinevates funktsioonides, nt rõhusõnad nii ja $k a-$ Meil on nii, Laual on ka; tegusõna juurde kuuluvad abimäärsõnad - saba jääb kinni; viisimäärused - suvi tuleb ruttu jne.

Kuigi ka venekeelsete õppijate A2-taseme tekstides leidub mustreid, mis sisaldavad kohamäärust, on neil selles funktsioonis tagasõnafraas, mida sarnasel moel pole esile tulnud ei soomekeelsetel õppijatel ega sihtkeeles, nt Paremal seina ${ }^{*}$ juures <ääres $>$ ja ${ }^{*}$ juures $<$ kõrval $>$ on valamu. Selliste mustrite ebaloomulikkus tuleneb kaassõna semantikast: sõna 
TEEL SiHtKeELEPÄrAse KEELEKASUtuse POOLE

juures tähendus võib olla üldistatud venekeelsete õppijate lähtekeele põhjal, ka kakskeelsetes sõnastikes on vene eessõna $y$ esimene tõlkevaste juures, järgnevad ääres, kõrval, all, ees, taga, lähedal.

Lisaks praktiseeritakse vene keele eessõna ja eesti keele kaassõna samastamist. Tõepoolest, kaassõna võib olla nimisõna ees nagu vene eessõnagi (nt вырос без оти-a 'kasvas üles ilma isa-ta, isa-ta'), kuid see on pigem erand, sest reeglina esineb kaassõna nimisõna järel (nt переночую $y$ mëm-u ‘ööbin tädi juures').

\subsubsection{B1-tase}

Soome- ja venekeelsete õppijate erinevus kaassõna ning määrsõna kasutamisel jätkub B1-tasemel, kuid see tendents ei ilmne enam niivõrd selgelt kui varem. Ühelt poolt on soomekeelsed õppijad hakanud kasutama kaassõnu samades mustrites, kus venekeelsedki (nt nimisõna-kaassõna-tegusõna); teisalt on ka venekeelsetel õppijatel lisandunud hulk mustreid, mis võivad sisaldada kuni kolm määrsõna (nt tegusõna-määrsõna-omadussõna, määrsõna-määrsõna-omadussõna, määrsõna-määrsõna-määrsõna). Ühelt poolt saab arvata, et tegemist on järk-järgulise lähenemisega sihtkeelepärasele keelekasutusele. Teisalt ei ole B1-taseme mustrite seast kuhugi kadunud need A2-taseme mustrid, mis pole sihtkeeles statistiliselt olulised või pole nende esinemus kuigi suur.

Vastupidi - neid on juurdegi tulnud. Näiteks mahub venekeelsete õppijate A2- ja B1-taseme sagedam kaassõna sisaldav muster nimisõnakaassõna-tegusõna B1-tasemel ka soomekeelsetel õppijatel statistiliselt oluliste hulka, ehkki selle esinemus on väike. Venekeelsetel õppijatel on selle mustri esinemus B1-tasemel keskmine, kuid kasutatakse endistviisi oma kodu ja esemete paiknemist kirjeldades. Tegemist on tagasõnafraasi sisaldava mustriga, millele regulaarselt järgneb tegusõna olema kindla kõneviisi oleviku ainsuse 3. pöördes, nt Valamu all on, Akna ees on, Köögikapi peal on. Mustri grammatiline varieerumine on minimaalne: reeglina olema, erandjuhul seisma, asuma ja rippuma, vaid mõnel juhul esineb lihtöeldise funktsioonis täistähenduslik tegusõna kindla kõneviisi 
olevikus mitmuse 3. pöördes. Kaassõnade hulk on A2-tasemega võrreldes suurem, korduvalt esinevad paiknemist tähistavad tagasõnad all, ees, vastas ja juures, ainukordselt vahel, kohal, peal, kõrval, ümber, taga, ääres. Kui A2-tasemel oli venekeelsetel õppijatel raskusi kaassõnade tähenduse tajumisega, siis B1-tasemel leidub vaid paar kahtlast tagasõnafraasi, mille loomulikkuses ei saa olla kindel - ${ }^{\star}$ Kapi ääres on, ${ }^{\star}$ Seina juures on.

Mustri nimisõna-kaassõna-tegusõna esinemus soomekeelsete õppijate B1-taseme tekstides on väike. Samas aga ei kirjelda nad tagasõnafraasi abil mitte niivõrd esemete-asjade paiknemist millegi-kellegi suhtes, kuivõrd kohta, kus miski-keegi oli, asus või elas. Tegusõna olema on sel juhul alati kindla kõneviisi lihtmineviku ainsuse 3. pöördes: Pargi juures oli, hoidja juures oli, Kiriku ees oli, Maja kõrval oli, Kodu lähedal oli.

Sihtkeeles on mustri nimisõna-kaassõna-tegusõna esinemus keskmine, sagedamad tagasõnad on ees, eest, juures, poole, taha ja otsa. Samas näitavad uurimistulemused, et nimisõna ja kaassõna järel eelistab emakeelekõneleja siiski määrsõna ning tegusõna nihkub mustrist vasakule hargnevasse konteksti, st et tavaliselt kasutatakse siin ühendtegusõna, nt mõtles juhtunu üle järele, paistis teki alt välja (vt Trainis \& Allkivi 2014: 288-290). Mõni analoogne järjend leidus ka venekeelsete õppijate tekstides, kuid nendes polnud ühendtegusõna (nt Maja kõrval vasakul). Tegelikult eelistab emakeelekõneleja hoopis niisugust kaassõna sisaldavat mustrit, mis algab tegusõnaga ning mille teine ja kolmas komponent moodustavad tagasõnafraasi (nt vaatas laua alla, tuli laua alt välja).

Ka määrsõna sisaldavate mustrite arv on B1-tasemel tervikuna kasvanud, sh venekeelsetel õppijatel. Niisuguseid mustreid oli kokku neliteist, üldjuhul jääb nende osakaal õppijate keelekasutuses samasse vahemikku, v.a muster tegusõna-määrsõna-omadussõna, mille levik on soomekeelsetel suur ja venekeelsetel keskmine. Mustri esinemus sihtkeeles on vähene (vrd tegusõnaga algavate mustrite klasse ning alamklasse Trainis \& Allkivi 2014: 286, 289-290 andmetel), kuid selle komponentide leksikaalne varieerumine on seevastu rikkalik, esile tuleb määrsõnade avar funktsionaalne võimekus jm (vt Eslon 2017: 30). Mustri grammatiline 
vormistus on kindlapiiriline. A2-tasemega võrreldes on seda mustrit asunud eriti aktiivsemalt kasutama soomekeelsed õppijad.

Üldiselt kasutavad õppijad B1-tasemel määrsõnu asjakohaselt, mõnel juhul võib nende valik olla isegi päris suur: sm - On küll hea, on väga erinev, On ka tore, on üsna väike; oli liiga külm, oli väga rahulik, oli natuke kurb; vn - on väga vana, on väga ${ }^{*}$ muusikaline $<$ musikaalne $>$, ${ }^{*}$ on väga käesolev, on väga sobiv, on kõige parem, on väga huvitavad, on väga tähtsad, on väga suured. Sellele vaatamata eelistavad venekeelsed õppijad endistviisi korrata määrsõna väga.

Edusamme mustri tegusõna-määrsõna-omadussõna kasutamisel saab hinnata võrdluses sihtkeele ja A2-taseme analüüsi tulemustega: muster muutub keerulisemaks vastavalt sellele, kuidas laieneb komponentide leksikaalne varieerumine, kaovad leksikaalsed ja grammatilised stereotüübid, tulevad kasutusse uued täistähenduslikud tegusõnad ja erinevad grammatilised vormid, avarduvad tegusõna ja määrsõna funktsioonid. Tuleb siiski tõdeda, et B1-tasemel pole venekeelsed õppijad vabanenud stereotüüpsusest: reeglina korratakse sõnakooslust on väga + omadussõna, samuti keskvõrde vormi (on kõige parem) ja hulgasõnafraasi (on palju erinevaid). Soomekeelsed õppijad pole mustrit stereotüüpselt kasutanud ei A2- ega B1-tasemel. Erinevalt emakeelekõnelejast piirduvad õppijad abitegusõnaga olema kindla kõneviisi olevikus ja lihtminevikus.

Niisiis on muster tegusõna-määrsõna-omadussõna esindatud mõlema rühma õppijate tekstides, kuid selle komponentide keeleline vormistus on erinev. Vastust vajab küsimus, miks sihtkeeles vähese esinemusega, kuid selge grammatilise vormistusega muster hakkab õppijatel B1-tasemel nii laialt levima.

Mustri määrsõna-määrsõna-omadussõna esinemus on vene- ja soomekeelsete õppijate tekstides väike, kuid sihtkeeles suur. Emakeelekõnelejat eristav tunnus on tihedad semantilised seosed kahe järjestikuse määrsõna vahel, mistõttu määrsõnakooslus võib hakata käituma kui leksikaalgrammatiline terviküksus. Õppijate puhul hakkab silma, et ühesuguseid määrsõnajärgnevusi pole korratud. See on kahtlemata 
samm edasi sihtkeelepärase määrsõnakasutuse poole. Nii oli venekeelsetel õppijatel mustri esimeses komponendis vaid üks sõnakordus (juba) ja soomekeelsetel mitte ühtegi. Teise komponendina on paaril-kolmel korral kasutatud rõhusõnu nii ja väga, nt juba nii kindel, veel nii väike, ka väga raske, võib-olla väga kuum. Omadussõna kordused puuduvad: vn - võib-olla isegi kinnine, praegu nii hull, mitte nii oluline; sm - küll nii tugev, üldsegi mitte uje, ikka tuubil täis. Soomekeelsete õppijate tekstidest leitud näited sisaldavad niisuguseid sihtkeele sõnu ja väljendeid, mis ei pruugi kuuluda isegi B2-taseme aktiivsesse sõnavarasse, nt uje, tuubil täis, ent teisalt esineb neil ka arusaamatuid sõnastusi nagu ?nii palju mugav, ?väga üle uhke, millega ei assotsieeru ühtegi sobivat konteksti.

\section{Mustrite dünaamika}

Sagedamate ühesuguse morfoloogilise struktuuriga mustrite esinemuse dünaamikat soome- ja venekeelsete õppijate A2- ning B1-taseme tekstides on kujutatud joonisel 3 .

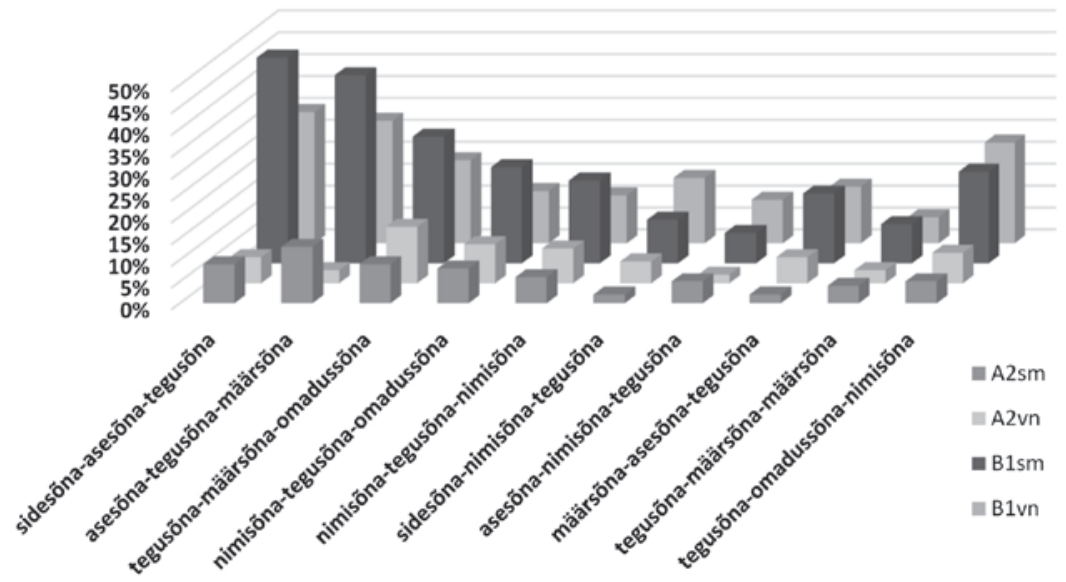

Joonis 3. Kümne sama struktuuriga mustri esinemus

A2- ja B1-tasemel 
TEEL SIHTKEELEPÄRASE KEELEKASUTUSE POOLE

Kaheteistkümnest A2-taseme sama struktuuriga mustrist on B1-tasemel kasutuses kümme: sidesõna-asesõna-tegusõna; asesõnategusõna-määrsõna; tegusõna-määrsõna-omadussõna; nimisõna-tegusõna-omadussõna; nimisõna-tegusõna-nimisõna; sidesõna-nimisõnategusõna; asesõna-nimisõna-tegusõna; määrsõna-asesõna-tegusõna; tegusõna-määrsõna-määrsõna; tegusõna-omadussõna-nimisõna. Joonisel 3 on näha, et samu mustreid, mis olid kasutuses A2-tasemel, on nii soome- kui ka venekeelsed õppijad hakanud B1-tasemel üldjuhul kasutama tunduvalt laiemalt, kuid nagu näitavad mustrite keeleanalüüsi tulemused, pole sellega kaasnenud erilisi kvalitatiivseid nihkeid.

Nii mõnegi mustri esinemus on A2-tasemega võrreldes suurenenud lausa hüppeliselt, nt sidesõna-asesõna-tegusõna. Seda ei saa seletada lihtsalt ülekasutusega. Motiveerituna suhtlusvajadusest on niisuguste mustrite leksikaalgrammatiline varieerumine soomekeelsetel õppijatel B1-tasemel kitsenenud või kinnistunud A2-taseme variandis, ent mustrit kui morfoloogilist struktuuri on võrreldes venekeelsete õppijatega kasutatud laiemalt, mis viitab keelekasutuse ökonoomsusele. Mustri sõnavara mitmekesisus näitab aga, et tegelikult toimub selle struktuuri alusel õppija sõnavara intensiivne laienemine. Näiteks: sm - aga ma ei, et ma ei, kui ma ei, kuigi ma ei; Et ma saan, Kui ma saan, siis ma saan, Et ma pean, sest ma pean; siis me läksime; kui ma *lopetasin<lõpetasin>, Siis ma parandasin; Kui ma olin, Siis ma jooksin; et ma võiksin, Ehk ma võiksin; kui mul on, et mul on, sest mul on, siis mul on; vn - sest see on, et see on; ja see on; kuid see on; et mina olen, et ma olen; siis ma kuulan, Aga ma *ülepingutan <pingutan üle>, sest ma mäletan, siis ma saan, et ma tahan; sest nad võivad; et ma óppisin, Siis ma töötasin; Aga mul on; siis sul on; et temal on, siis tal on; Kui mul ei, et mul ei; Aga see ei; et ma ei, siis ma ei, Ja ma ei; Kui sa ei; siis ta ei; Et nad ei. Mõlema rühma õppijad kasutavad mustrit nii lause alguses kui ka lause sees, ent selle leksikaalne ja grammatiline varieerumine on erinev.

B1-tasemel on laienenud sidesõnade ja asesõnade valik. Analoogselt A2-tasemega kasutavad erikeelsed õppijad sündmusi ja olukordi kirjeldades ka B1-tasemel ainsuse 1. isikut ( $m a)$ subjekti funktsioonis, 
lisandub omaja funktsioon $(\mathrm{mul})$. Soomekeelsetel õppijatel kitseneb B1-tasemel asesõna valik, kasutusse jääb ainsuse 1. isik ma (mina) aluse funktsioonis. Seevastu venekeelsetel õppijatel tuleb juba A2-tasemel esile ainsuse 2. isiku lühivorm sa ülekantud tähenduses, B1-tasemel lisandub erinevat liiki asesõnu, millest eriti aktiivselt kasutatakse näitavat asesõna see, järgnevad isikulise asesõna ainsuse 1. ja 3 . isik $(m a, t a)$ ning mitmuse 3. isik (nad), harvem ainsuse 1., 2. ja 3. isik omaja funktsioonis ( $m u l$, sul, tal).

Tegusõnadest eelistavad soome- ja venekeelsed õppijad A2-tasemel täistähenduslikke tegusõnu, harva kasutatakse abitegusõna olema kindla kõneviisi olevikus ainsuse 1., harva 3. pöördes. B1-tasemel täieneb soomekeelsete õppijate tegusõnade pagas erinevate täistähenduslike tegusõnade ja liikumist väljendavate tegusõnadega kindla kõneviisi oleviku, harvem lihtmineviku ainsuse (mitmuse) 1. pöördes. Vähemal määral esineb modaaltähenduslikke abitegusõnu koos ma- või dategevusnimega (nt pean tegema, saan teha), sh võima tingiva kõneviisi oleviku ainsuse 1. pöördes; harva olema koos ainsuse 1. isikuga omaja funktsioonis $(m u l)$. Niisiis on soomekeelsetel õppijatel tegusõnade leksikaalne ja grammatiline varieerumine B1-tasemel üsna mitmekesine.

Venekeelsed õppijad seevastu eelistavad ka B1-tasemel jaatavas kõnes abitegusõna olema kindla kõneviisi oleviku ainsuse 3. pöördes (analoogia emakeelekõnelejaga) ja eitavas kõnes koos ainsuse 1., 2. ja 3. isikuga omaja funktsioonis ( $m u l, s u l, t a l)$. Rööpselt esineb erinevaid täistähenduslikke tegusõnu ja modaalseid abitegusõnu kindla kõneviisi olevikus (harvem lihtminevikus). Vaatamata sellele, et mustri sidesõnaasesõna-tegusõna leksikaalne ja grammatiline varieerumine on mõlema rühma õppijatel B1-tasemel üsna mitmekesine, kalduvad venekeelsed stereotüüpse sõnastuse sest (et) see on poole, mida soomekeelsetel ei esine, v.a üks juhtum - kui see on. Soomekeelsete õppijate keelekasutuses ilmneb B1-tasemel asesõna valikuga seotud piiranguid, millest sõltub ka tegusõna vorm. Sama tendents ilmestab ka sihtkeele eelistusi.

Mustri sõnavara mitmekesisus soomekeelsetel õppijatel näitab, et tegelikult toimub mustri alusel õppija sõnavara intensiivne laienemine. 
TEEL SIHTKEELEPÄRASE KEELEKASUTUSE POOLE

Venekeelsete õppijate B1-taseme tekstides on sama mustri esinemus väiksem, kuid morfosüntaktiline varieeruvus seevastu suurem kui soomekeelsetel õppijatel. See viitab mustri sidesõna-asesõna-tegusõna ekstensiivsele laienemisele, mille käigus sõnavara kuigi oluliselt ei täiene, küll aga muutub morfosüntaks mitmekesisemaks. Tegemist on olukorraga, kus uudsete vormivalikutega ei kaasne sõnavara laienemist eelistatakse ühte kindlat tüüpi sõnastust, mille õppijad on omandanud. Stereotüübid esinevad rööpselt mustri morfosüntaktilise mitmekesisuse ekstensiivse laienemisega isegi siis, kui konkreetne muster ei ole sihtkeelele omane või on selle esinemus sihtkeeles statistiliselt ebaoluline.

Niisiis areneb soomekeelsetel õppijatel A2-tasemelt B1-tasemele liikudes mustri sidesõna-asesõna-tegusõna alusel enim sõnavara, venekeelsetel õppijatel aga morfosüntaktiline varieeruvus. Ehk teisisõnu: väljaspool keelekeskkonda ilmneb suundumus sõnavara omandamisele, keelekeskkonnas aga suundumus grammatika omandamisele. Üks võimalik põhjus võib olla eesti ja soome keelesüsteemide sarnasuses: soomekeelsed õppijad mõistavad juba esmasel kokkupuutel sihtkeelega, et see toimib üldjoontes samamoodi kui nende emakeel (Kaivapalu \& Muikku-Werner 2010; Kaivapalu \& Martin 2014, 2017).

Nii A2- kui ka B1-tasemel iseloomustab stereotüüpsus vaid venekeelseid õppijaid, sellel on seos asesõna ja määrsõna kasutusega. Näiteks eespool kirjeldatud mustri sidesõna-asesõna-tegusõna (et nad on, siis sul on, siis tal on, aga ma arvan, et ma óppisin, et mul ei ole jmt) puhul esineb ulatuslikult näitava asesõna stereotüüp sest/et see on. Soomekeelsetel õppijatel asesõnalist stereotüüpi ei ole, sest muster on kasutusel kitsamal suhtluseesmärgil (minakeskne kirjeldus), morfosüntaktiliselt vähem varieeruv, ent samas leksikaalselt mitmekesine (nt et ma ei, aga ma ei saa, kui mul on, siis ma jooksin, siis me jalutasime, et ma võiksin). Ka mustri asesõna-tegusõna-määrsõna puhul on venekeelsete õppijate B1-taseme tekstides valdavalt kasutusel stereotüüp see on väga/kõige, millele soomekeelsed õppijad eelistavad mustris isikulist asesõna (nt ma ópin kiiresti, me jalutasime kaua, mul on vaja) ning näitavat asesõna kasutatakse üldse väga harva (nt see oli natuke, see on nii). 
Määrsõnadega on venekeelsetel õppijatel kujunenud teistlaadi stereotüüpe: nt mustris tegusõna-määrsõna-määrsõna kombineeritakse omavahel märssõnu väga, palju ja vaja: on vaja palju, on palju vaja, on vaja väga, on väga vaja, on väga palju, oli väga palju. Niisuguseid määrsõnakooslusi ei esine soomekeelsetel õppijatel, määrsõnu palju ja väga ei kombineerita omavahel: on nii palju, on ka väga. Tavaliselt kasutatakse koos erinevat liiki määrsõnu nagu oli küll lähedal, on ikkagi üleliia. Peale selle on soomekeelsetel õppijatel ka mustris tegusõna-määrsõna-omadussõna juba A2-tasemel neljast sõnast koosnev määraskaala (mõnevõrra > üsna > eriti > väga), kuid venekeelsetel õppijatel esineb stereotüüpselt rõhusõna väga (on väga ilus). Soomekeelsete õppijate määraskaala täieneb B1-tasemel mustris tegusõna-tegusõna-määrsõna, koosnedes seitsmest sõnast (üldsegi $\sim$ sugugi $>$ eriti $>$ rohkem $>$ küllalt $>$ piisavalt $>$ palju). Samas kordavad venekeelsed õppijad tüüpiliselt nelja sõna - väga, nii, palju ja kõige. Olgugi et B1-tasemel täieneb mõlema rühma õppijate määrsõnade pagas, jääb see venekeelsetel endiselt kasinaks. Jätkuvalt eelistatakse rõhusõna väga (nt on väga vana, oli väga huvitav) ja ülivõrde vormi, nt on kõige parem.

Venekeelsed õppijad ei kasuta B1-tasemel abstraktseid nimisõnu, vaid piirduvad konkreetsete nimisõnadega iseennast ja oma peret või lähikonda tutvustades, nt muster asesõna-nimisõna-tegusõna - minu nimi on, minu isa on, samuti kodu, ametit või ümbritsevat keskkonda kirjeldades, nt muster nimisõna-tegusõna-nimisõna - majas on keskküte, diivanilaual on laserplaadimängija. Nii polegi venekeelsetel õppijatel B1-tasemel ka mustri tegusõna-omadussõna-nimisõna kasutamisel märgata kvalitatiivseid arenguid. Valdav osa omadussõna-nimisõna kooslustest on vabad sõnaühendid, mida kasutatakse samamoodi nagu A2-tasemel ning endiselt oma kodu, elamist ja õpinguid kirjeldades.

Samas pole soomekeelsete õppijate kirjutistes teemaga seotud leksikaalsed piirangud niivõrd reljeefselt esile tulnud, ehkki ka nemad kirjutavad iseendast, oma lähedastest, kodust, õpingutest jmt. Näiteks mustris tegusõna-omadussõna-nimisõna kasutavad soomekeelsed õppijad mitmekesisemat sõnavara kui venekeelsed, ka omadussõna-nimisõna 
TEEL SIHTKEELEPÄRASE KEELEKASUTUSE POOLE

kooslused on neil sihtkeelepäraselt loomulikud, nt tedretäheline nöpsnina, tasane maa, lai naeratus. Analoogne erisus tuleb esile soome- ja venekeelsetel õppijatel ka B1-taseme uute mustritega (nt omadussõnanimisõna-tegusõna, sidesõna-omadussõna-nimisõna, määrsõna-määrsõna-omadussõna), milles soomekeelsete õppijate tekstidest leitud omadussõna-nimisõna ja määrsõna kooslused ei viita temaatilistele piirangutele.

Mustris asesõna-tegusõna-määrsõna eelistavad soomekeelsed õppijad nii A2- kui ka B1-tasemel erinevaid täistähenduslikke tegusõnu (abitegusõna olema esineb harva). Koos uute tegusõnadega tulevad esile erinevad süntaktilised struktuurid, rööpselt mitmekesistub määrsõnade valik, nt ma kavatsen ka mida teha, ma pean tihti mida tegema, me jalutasime kaua kus, mul on vaja mida-keda, mida teha. Seevastu venekeelsed õppijad kasutavad stereotüüpselt abitegusõna olema (täistähenduslikke tegusõnu tuleb harva ette), näitavat asesõna see ja rõhusõna väga, nt see on/oli väga, see on/oli palju, see on/oli kõige. Mustri leksikaalgrammatiline varieerumine pole neil seotud tegusõnaga, selle asemel varieeritakse asesõna subjekti (harva omaja) funktsioonis. Sihtkeeles tuleb mustris asesõna-tegusõna-määrsõna esile rikkalik valik erinevaid tegusõnu ja määrsõnu, mustri grammatiline varieerumine on seotud ennekõike tegusõna ajavormidega, muster avab määrsõnade funktsionaalse võimekuse.

Mõlema rühma õppijate keelekasutuses on üksjagu suur esinemus mustritel, mille osakaal sihtkeeles on vähene või statistiliselt ebaoluline. Niisugune on näiteks muster tegusõna-määrsõna-omadussõna (on küll hea, on väga huvitavad, oli natuke kurb, oli veel märg), mida emakeelekõneleja kasutab suhteliselt harva, kuid mille grammatiline vormistus on selgelt piiritletud ja sõnavara rikkalik (on nii selge, olid hästi sõbralikud, avaneb sootuks uus lehekülg, tundus nii värske). B1-taseme mustri keeleanalüüs näitas, et venekeelsed õppijad kasutavad seda mustrit stereotüüpselt: reeglina korratakse sõnakooslust on väga + omadussõna, samuti keskvõrde vormi (on kõige parem) ja hulgasõnafraasi (on palju erinevaid). Põhjuseks jällegi määrsõnade minimaalne leksikaalne 
varieerumine. Seevastu soomekeelsed õppijad kasutavad mustrit tegusõna-määrsõna-omadussõna aktiivselt just tegusõnade, määrsõnade ja omadussõnade pagasi suurendamiseks.

Olemuselt teistlaadne on sihtkeeles statistiliselt ebaolulise mustri laialdane levik õppijakeeles, kui see on vastuolus emakeelekõneleja loomuliku keelekasutusega. Näiteks venekeelsed óppijad on eelistanud mustrit määrsõna-asesõna-tegusõna (praegu ma saan, Kõigepealt see on, isegi ma olen), st sõnajärge määrus-alus-öeldis. Sama esineb ka soomekeelsetel õppijatel (Loodetavasti ma võin, seal ma saan, Loomulikult ma teen) ja sihtkeeles, kus loomulikumaks peetakse siiski sõnajärge määrus-öeldis-alus, st mustrit määrsõna-tegusõna-asesõna (Seal olen ma palju aega veetnud, praegu saan ma vaid kahetseda, et.., Kõigepealt on see kallis, Loodetavasti võin ma ise otsustada, seal saan ma rahus olla). Vene keeles on sõnajärg määrus-alus-öeldis normatiivne ning määrusöeldis-alus ehk V2-sõnajärg kuulub lähtekeele ekspressiivse süntaksi vahendite hulka, mistõttu seda sihtkeeles üldjuhul ka välditakse (täpsemalt vt Kaivapalu 2010). Eesti keeles on V2-sõnajärg normatiivne, selle alusel moodustuvad keeleomased määrsõna-tegusõna kooslused, millega assotsieeruvad tüüpilised kasutuskontekstid. V2-sõnajärg ei ole normatiivne ka soome keeles, kuid õppijad kasutavad B1-tasemel mustris määrsõna-asesõna-tegusõna sobivalt $l t$ - ja sti-lõpulisi subjektiivmodaalse ja hinnangulise tähendusega määrsõnu, samuti aega ja kohta tähistavaid määrsõnu, mis viitab diskursuse tunnetamisele ja vajaliku sõnavara olemasolule (sh modaalsed ja liikumist väljendavad tegusõnad), millest venekeelsetel õppijatel jääb vajaka, nt *väga ma tulen, ${ }^{*}$ Veel ma võin, ${ }^{*}$ veel ma töötan, ?isegi ma olen, ${ }^{*}$ kaua ma elan.

A2- ja B1-taseme keelekasutusmustrite võrdleva analüüsi tulemused näitavad, et semantiline mitmekesisus määrab paljuski mustrite grammatilise ja funktsionaalse varieeruvuse piire ning leksikaalgrammatilisi piiranguid. Selles aspektis on lisaks leksikaalsetele kooslustele (seotud sõnaühendid, kollokatsioonid ja idioomid) oluline teada sihtkeele elementide kooskasutuse leksikaalgrammatilisi seaduspärasusi ehk reegleid, mis ilmestavad mustrite kasutamist sihtkeeles. Näiteks järjendi 
tegusõna-omadussõna-nimisõna puhul tuleb lisaks omadussõnanimisõna vastastikusele semantilisele sobivusele (nt kõrge $\sim$ madal vili, kuid pikk poiss, osavad käed, must auk, terav keel) arvestada keeruliste seostega sõnajärje, öeldise tüübi, tegusõna tähenduse, rektsioonistruktuuri ja mustri komponentide vormivarieeruvuse vahel, mis teeb pealtnäha lihtsa struktuuriga mustri sihtkeelepärase kasutamise õppija jaoks raskeks. Ilmselt sel põhjusel piirdutakse isegi B1-tasemel abitegusõnaga olema kindla kõneviisi oleviku ainsuse 3. pöördes, selle asemel et tegusõnade pagasit laiendades minna edasi sihtkeelepärase mustrikasutuse suunas (tekkis ähmane lootuskiir, püstitas tavatu küsimuse, kas.. , ootasid päästvat telefonihelinat, on tehtud uusi ettepanekuid, kalla punasest termosest jne). Analoogne tendents ilmneb ka teise struktuuri poolest lihtsa B1-taseme mustriga nimisõna-tegusõna-nimisõna, kus vene- ja soomekeelsete õppijate keelekasutusest on kõrvale jäänud sihilised tegusõnad täis- või osasihitisega (nt Jumal lõi maailma).

Ka semantiliselt sobivad määrsõnakooslused on õppija jaoks A2- ja B1-tasemel probleem. Neid on üldiselt vähe analüüsitud ja kirjeldatud, kuid need esinevad regulaarselt sihtkeeles. Näiteks B1-tasemel lisandunud mustris sidesõna-määrsõna-määrsõna eelistatakse sihtkeeles kolme varianti: sagedam on ja .. nagu (ja vist, pisut, kuskilt nagu); järgnevad aga/ja ka (aga ka päris, ja ka natuke) ning ja/ning .. ka (ja muidugi ka, ning omamoodi ka) (vt Trainis \& Allkivi 2014: 295). Sihtkeelepäraste määrsõnakoosluste moodustumise seaduspärasusi tundmata hakatakse kombineerima kolme või nelja sagedamat määrsõna, nagu venekeelsed óppijad stereotüüpselt teevadki: on/oli vaja palju > palju vaja > vaja väga $>$ väga vaja > väga palju vaja jne.

\section{Kokkuvõtvalt vene- ja soomekeelsete õppijate keelekasutusest}

Siinse uurimuse eesmärk oli selgitada, kuidas muutub eesti keele õppijate kirjalik keelekasutus teel algaja keelekasutaja (A2) tasemelt iseseisva keelekasutaja (B1) tasemele ning millised suundumused seda protsessi 
ilmestavad. Uurimuse tulemused osutavad alljärgnevaid sarnasusi ja erinevusi vene- ja soomekeelsete õppijate sihtkeele kasutuses.

Vahed sama morfoloogilise struktuuriga mustrite esinemuses soome- ja venekeelsetel õppijatel näitavad, et A2-tasemel on üks võrdselt levinud muster (nimisõna-sidesõna-nimisõna - õde ja vend, vannituba ja köök) ja kolm lähedase levikuga mustrit (nimisõna-tegusõna-määrsõna - päike tõuseb vara, Suvel on palju, nimisõna-tegusõna-omadussõna - ilm on hea, Seinal on ilus, tegusõna-määrsõna-määrsõna - on $i k k a k a$, on väga palju). Nende leksikaalgrammatiline varieerumine on ühesugune järjendites nimisõna-sidesõna-nimisõna ja nimisõna-tegusõna-omadussõna, ent erinev kahes määrsõna sisaldavas mustris. See on seotud tegusõna ja määrsõna valikuga: a) venekeelsed õppijad kasutavad vaid abitegusõna olema, soomekeelsed lisaks ka täistähenduslikke tegusõnu - järelikult on vene- ja soomekeelsed õppijad neid mustreid kasutanud erinevate süntaktiliste struktuuride alusel; b) venekeelsed kasutavad valdavalt rõhusõna väga (harvem palju), soomekeelsetel on määrsõnade pagas mitmekesisem. Sõnavara piiratusest tingituna on venekeelsed õppijad nimetatud kahte lähedase esinemusega mustrit kasutanud stereotüüpselt - elu on väga, Sõbrad on väga, Eestis on väga; on ka väga, on väga tihti, on väga palju). Tänu suuremale tegusõna ja määrsõna pagasile pole soomekeelsetel õppijatel nende mustrite kasutuses stereotüüpsust kujunenud.

B1-tasemel on ühesugune esinemus kolmel mustril (määrsõnategusõna-määrsõna - Siin on väga, praegu on palju, sees oli väga, Seal oli palju, tegusõna-määrsõna-nimisõna - on palju ${ }^{\star}$ taime, ${ }^{\star}$ lille $<$ taimi, lilli>, on vaja *keeleoskus <keeleoskust>, on ka köögikapp, on nüüd märts, oli juba öö, tegusõna-tegusõna-omadussõna - ei ole sarnane, ei ole kiire) ning kahe mustri esinemus on lähedane (asesõna-tegusõnaomadussõna - See on suur, ma olen kindel, Ma olin rõõmus, See on võimalik, Mul on väike, nimisõna-tegusõna-tegusõna - elu ei ole, korteris ei ole, korter on erastatud). Loetletud mustrite seas on ühesuguse leksikaalgrammatilise vormistusega vaid üldeituse muster tegusõna-tegusõna-omadussõna. Ülejäänud kokkulangeva või lähedase esinemusega 
mustrites on soome- ja venekeelsete õppijate keelekasutuseelistused erinevad. Mustris määrsõna-tegusõna-määrsõna kasutavad venekeelsed õppijad abitegusõna olema olevikus ja soomekeelsed lihtminevikus. Mustris tegusõna-määrsõna-nimisõna on venekeelsetel õppijatel abitegusõna olema oleviku vorm kasutusel koos hulgasõnafraasi ja modaalsõnaga vaja - sellele järgnev nimisõna peaks olema osastavas käändes, kuid venekeelsed õppijad kasutavad reeglina nimetavat käänet. Tegemist on veamustriga. Soomekeelsetel óppijatel vaheldub abitegusõna olema oleviku ja lihtmineviku vorm. Mustris nimisõna-tegusõna-tegusõna eelistavad venekeelsed õppijad eitava kõne olevikku (abitegusõna olema) ning soomekeelsed jaatava kõne täisminevikku (erinevad täistähenduslikud tegusõnad). Muster asesõna-tegusõna-omadussõna on grammatiliselt varieeruvam venekeelsetel õppijatel, kuid erinevalt soomekeelsetest ei kasuta nad subjekti omaja funktsioonis.

Mõlema rühma õppijate mustrite keelelisel vormistamisel tuleb esile erinevus kaassõna ja määrsõna kasutamisel. Venekeelsed õppijad eelistavad kaassõna ja soomekeelsed määrsõna sisaldavaid mustreid. See tendents on läbiv, kuigi B1-tasemel hakkavad ka soomekeelsed õppijad tasapisi kasutama ühte kaassõna sisaldavat mustrit, mis on venekeelsetel kasutuses A2-tasemest peale (nimisõna-kaassõna-tegusõna), ning venekeelsete õppijate B1-taseme tekstides ilmneb kuni kolm määrsõna sisaldavaid mustreid, sh uusi (nt tegusõna-määrsõna-omadussõna, määrsõna-määrsõna-omadussõna, määrsõna-määrsõna-määrsõna, määrsõna-tegusõna-tegusõna, määrsõna-tegusõna-nimisõna). Üldiselt aga on venekeelsete õppijate määrsõnade pagas üsna kesine, samade sõnade kordamine erineva struktuuriga mustrites tavaline ning kujundab koos abitegusõna olema oleviku vormiga mustri stereotüüpsust.

\section{Järeldusi sihtkeeleoskuse arenemise kohta}

Õppijate keelekasutus peegeldab ühelt poolt sihtkeele omandamise üldisi suundumusi, teisalt eri emakeelega õppijarühmade keeleoskuse erisusi. Vene- ja soomekeelsete eesti keele õppijate A2- ja B1-taseme 
keelekasutusmustrite analüüs võimaldab teha esialgseid järeldusi eesti keele oskuse arengu kohta algaja keelekasutaja tasemelt iseseisva keelekasutuseni ning vaadelda muu hulgas keelekeskkonna ja keelesugulusest tuleneva keeltevahelise sarnasuse rolli keele omandamisel.

Uurimuse tulemused osutavad, et mõlema õppijarühma keelekasutuses kasvab A2-tasemega võrreldes mustrite koguarv ning statistiliselt oluliste mustrite arv ja osakaal. Samuti suureneb oluliselt, pea kolmekordseks, sama struktuuriga mustrite arv. Niisiis toimub A2- ja B1-taseme vahel keeleoskuse areng mustrite esinemuse, kasutussageduse ja leksikaalgrammatilise varieerumise osas. Samas näitab keelekasutusmustrite analüüs kahe õppijarühma keeleoskuse arengu erinevat suundumust.

Venekeelsete õppijate tekstides kasvab A2-tasemelt B1-tasemele liikudes mustrite kasutussagedus järsult, kuid sellega ei kaasne mustrite rühmade olulist laienemist ega sõnavara märkimisväärset mitmekesistumist. Seega toimub venekeelsete õppijate keeleoskuses A2-taseme algajast keelekasutajast B1-taseme iseseisvaks keelekasutajaks kujunemisel soomekeelsetest õppijatest erinevalt hüppeline morfosüntaktiline areng mustrite keerukust väljendava laiema varieeruvuse suunas. Kuigi B1-tasemel areneb ka sõnavara, jääb see ka B1-tasemel veel üsna stereotüüpseks. Tegemist on olukorraga, kus uudsete vormivalikutega ei kaasne sõnavara laienemist: õppijad eelistavad kindlat, eelnevalt omandatud sõnastust. Stereotüüpne sõnastus esineb koos mustri morfosüntaktilise mitmekesisuse ekstensiivse laienemisega isegi siis, kui see muster ei ole sihtkeelele omane või on selle esinemus statistiliselt ebaoluline. Soomekeelsete õppijate kirjutistes seevastu kasvab statistiliselt oluliste mustrite osakaal sujuvalt. Vähemate mustrite alusel toimub õppija sõnavara intensiivne laienemine: tekstides esineb isegi kõrgematel keeleoskustasemetel harva kasutatavaid sihtkeele sõnu ja väljendeid.

Niisiis areneb venekeelsetel õppijatel A2-tasemelt B1-tasemele liikudes enam morfosüntaks, soomekeelsetel õppijatel aga sõnavara. Võib arvata, et keelekeskkond toetab venekeelseid õppijaid: neil on keelekeskkonna toel tekkinud teatud kindlustunne ja julgus, aga ka 
vajadus katsetada morfosüntaktiliselt erinevaid väljendusviise, mis nende emakeelest erinevad. Hüpoteeside testimine toimub pigem juba omandatud sõnavara põhjal, sest õppijate keeletöötlusvõimel on piirid. Soomekeelsed õppijad seevastu on teadlikud lähisugulaskeelte süsteemide sarnasusest ja kogenud, et sihtkeel toimib üldjoontes samamoodi kui nende emakeel. Nii võimaldavadki emakeelepõhised teadmised sihtkeele morfosüntaksist ja kahe keele ühisest sõnavarast laiendada oma sõnavara keerukama sihtkeelepärase väljenduse suunas. Seega ilmneb sarnase sihtkeele õppimisel väljaspool keelekeskkonda suundumus sõnavara omandamisele, emakeelest erineva sihtkeele õppimisel keelekeskkonnas aga suundumus mustri morfosüntaksi omandamisele. Neid suundumusi on põhjust arvestada nii eesti keele õpetamisel sihtkeelena kui ka sihtkeele õpetamisel üldisemalt: emakeelest erineva morfosüntaksiga keele puhul vajab sõnavara laiendamine õpetamisel enam teadlikku tuge ja peaks toimuma omandatud keelekasutusmustrite põhjal seostatuna õpitava teemaga. Emakeele ja keelekeskkonna rolli üksikasjalikum selgitamine on aga juba järgmiste uurimuste teema.

\section{Kirjandus}

Eslon, Pille 2014. Adverbi sisaldavate struktuuride tekstifunktsioonidest eesti ilukirjandus- ja õppijakeeles ['Constraints on morphosyntactic and lexical variability']. - Lähivõrdlusi. Lähivertailuja 24, 15-46. https://doi. org/10.5128/LV24.01

Eslon, Pille 2017. Keelekasutusmustrid verbist paremal: morfosüntaktiline ja leksikaalsemantiline varieerumine ['Patterns of language use found on the right periphery of the verb: Morphosyntactic and lexico-semantic variability']. Lähivõrdlusi. Lähivertailuja 27, 17-64. https://doi.org/10.5128/LV27.01

Eslon, Pille, Kais Allkivi-Metsoja 2018. Teksti keelekasutusmustrid ja lingvistiline klasteranalüüs ['Patterns of language use and linguistic cluster analysis']. Lähivõrdlusi. Lähivertailuja 28, 21-46. https://doi.org/10.5128/LV28.01

Eslon, Pille, Erika Matsak 2009. Eesti keele kasutusvariandid: korpustest tulenev käändevormide võrdlev analüüs ['Corpus-driven comparative analysis of variants of Estonian']. - Eesti Rakenduslingvistika Ühingu aastaraamat 5, 79-110. https://doi.org/10.5128/ERYa5.06 
Granger, Sylviane 1996. From CA to CIA and back: An integrated approach to computerized bilingual and learner corpora. - Karin Aijmer, Bengt Altenberg, Mats Johansson (eds.). Languages in Contrast: Papers from a Symposium on Text-based Cross-linguistic Studies. Lund Studies in English 88. Lund: Lund University, 37-51.

Ivaska, Ilmari 2015. Tracing crosslinguistic influences in structural sequences: What does key structure analysis have to offer? - Bergen Language and Linguistic Studies 6, 23-44. https://doi.org/10.15845/bells.v6i0.807

Jarvis, Scott 2010. Comparison-based and detection-based approaches to transfer research. - EUROSLA Yearbook 10 (1), 169-192. https://doi.org/10.1075/ eurosla.10.10jar

Jürine, Anni, Külli Habicht 2017. Grammaticalization of complex items: Estonian nii et 'so that', 'so'. - ESUKA/JEFUL 8 (2), 35-58. https://doi.org/10.12697/ jeful.2017.8.2.02

Kaivapalu, Annekatrin 2010. Mõnede eesti sõnajärjemallide psühholingvistilisest reaalsusest ['On psycholinguistic reality of some word order patterns of Estonian']. - Eesti Rakenduslingvistika Ühingu aastaraamat 6, 103-120. http://dx.doi.org/10.5128/ERYa6.07

Kaivapalu, Annekatrin, Maisa Martin 2014. Measuring Perceptions of CrossLinguistic Similarity between Closely Related Languages: Finnish and Estonian Noun Morphology as a Testing Ground. - Heli Paulasto, Lea Meriläinen, Helka Riionheimo, Maria Kok (eds.). Language Contacts at the Crossroads of Disciplines. Cambridge Scholars Publishing, 283-318.

Kaivapalu, Annekatrin, Maisa Martin 2017. Percieved similarity between related languages: Strings of letters or morphological units? - Nordic Journal of Linguistics 40 (2), 149-174. https://doi.org/10.1017/S0332586517000142

Kaivapalu, Annekatrin, Pirkko Muikku-Werner 2010. Reseptiivinen monikielisyys: miten suomenkielinen oppija ymmärtää viroa äidinkielensä pohjalta? ['Receptive multilingualism: How Finnish as a first language helps learners to understand Estonian']. - Lähivõrdlusi. Lähivertailuja 20, 68-96. https:// doi.org/10.5128/LV20.03

Kyle, Kristopher, Scott Crossley, Jianmin Dai, Danielle S. McNamara 2013. Native language identification: A key n-gram category approach. - Proceedings of the Eighth Workshop on Innovative Use of NLP for Building Educational Applications. Atlanta, Georgia, Association for Computational Linguistic, 242-250. https://1library.net/document/q05rx13y-native-language-identification-key-n-gram-category-approach.html?tab=pdf (12.5.2020). 
Ots, Sander 2012. Statistikapõhise tarkvara loomine morfoloogiliste kollokatsioonide eraldamiseks eesti keele tekstidest ['Software for Morphosyntactic Cluster Extraction from Estonian Texts']. Bakalaureusetöö. Tallinn: Tallinna Ülikool.

Trainis, Jekaterina, Kais Allkivi 2014. Ilukirjanduskeelest uue pilguga ['On belletristic language from a new perspective']. - Eesti Rakenduslingvistika Ühingu aastaraamat 10, 283-306. https://doi.org/10.5128/ERYa10.18

Voolaid, Katrin 2018. Vene ja soome lähtekeelega õppijate eesti keele kasutusmustrid (B1-tase) ['Estonian language usage patterns among Russian and Finnish students (B1 language proficiency level)']. Magistritöö. Tallinn: Tallinna Ülikool.

\section{Pille Eslon}

Tallinna Ülikool, digitehnoloogiate instituut

Narva mnt 29, 10120 Tallinn, Estonia

peslon@tlu.ee

\section{Annekatrin Kaivapalu}

Itä-Suomen yliopisto, humanistinen osasto, suomen kieli ja kulttuuritieteet

PL 111

80101 Joensuu, Finland

annekatrin.kaivapalu@uef.fi 


\title{
Towards target-like language use: Russian and Finnish learners' dynamics of written Estonian on A2- and B1-level
}

\author{
PILLE ESLON ${ }^{1}$, ANNEKATRIN KAIVAPALU ${ }^{2}$ \\ Tallinn University ${ }^{1}$, University of Eastern Finland ${ }^{2}$
}

The paper deals with the Russian and Finnish learners' use of written Estonian on the proficiency levels A2 and B1. Russian learners acquired Estonian as a second language in Estonia, Finnish learners learned Estonian as a foreign language in Finland. The aim of the study is to find out the main characteristics of learner language development from $\mathrm{A} 2$ to $\mathrm{B} 1$ level of both of the learner groups and also shed light on the first language influence and on the impact of language environment. The study is based on the analysis of the most frequent morphosyntactical patterns in the texts of Estonian Interlanguage Corpus. Target language use of the two learners' groups is compared with each other and with the use of native Estonians. The data consists of the actively used trigrams: 203 trigrams of Russian and 227 of Finnish learners on the A2-level, and 4363 of Russian and 1132 of Finnish learners on the B1-level.

The results of the study show that the language use of the two learner groups develops from A2 to B1 level similarly in many ways. However, in the texts of Russian learners the total amount of patterns as well as the amount of statistically relevant patterns grow rapidly on the level $\mathrm{B} 1$. At the same time the variety of the pattern groups and vocabulary exhibit less expansion. In the texts of Finnish learners the presentage of statistically relevant patterns grows steadily, but at the same time the extensive development of vocabulary on the basis of smaller amount of patterns can be detected. Thus, from the A2 to B1 level, the acquisition of closely related target language outside language environment is characterized mainly by the development of vocabulary while in the acquisition of different target language in language environment the main characteristic is extensive development of morphosyntax.

Keywords: learner language; written texts; morphosyntactical patterns; variation; Estonian; Russian; Finnish 